\title{
DIVERSITY AND PASTORAL VALUE OF HERBACEOUS VEGETATION IN SAVANNAH ECOSYSTEMS IN THE SUDANO-SAHELIAN ZONE OF CAMEROON: CASE OF THE MAYO-DANAY DIVISION (FAR-NORTH REGION)
}

\author{
BAKOULOU NGAMO Africa ${ }^{1 *}$, SOUARE Konsala ${ }^{1}$, IBRAHIMA Adamou ${ }^{2}$ \\ ${ }^{1 *}$ University of Maroua, Faculty of Sciences, Department of Biological Sciences, PO Box: 814 Maroua, Cameroon; \\ ${ }^{2}$ University of Ngaoundéré, Faculty of Sciences, Department of Biological Sciences, PO Box: 454 Ngaoundéré, \\ Cameroon; \\ *Corresponding Author BAKOULOU NGAMO Africa, e-mail : afbakoulou@gmail.com;
}

Received January 2021; Accepted February 2021; Published March 2021;

DOI: https://doi.org/10.31407/ijees11.206

\begin{abstract}
Savannah ecosystems play an important economic role at the agrosylvopastoral level. However, agriculture and pastoral activities constitute the main human pressures on these ecosystems. These activities are exacerbated by bushfires which are common in this sudano-sahelian zone of Cameroon. The objective of this study was to characterize the floristic diversity of the herbaceous vegetation in the Sudano-Sahelian zone of Cameroon. The aligned quadrat points method was used for the floristic surveys. The experimental design consisted of four treatments which were the Subdivisions and three repetitions which were three villages per treatment. In the savannah ecosystem of each village, an aligned quadrat point $(50 \mathrm{~m} \times 50 \mathrm{~m})$ has been installed and along each $25 \mathrm{~m}$ half-diangonal, ie 100 aligned points, all the herbaceous plants were inventoried. The analysis of variances was used to test the levels of specific diversity of plant formations in villages and subdivisions. Records include 71 herbaceous species belonging to 66 genera and 21 families in our study area. Species with strong contributions to specific recoveries for all sites were Pennisetum pedicelatum, P. polystachion, Hyparrhenia rufa, H. hirta, Aristida adscensionis, A. hordeacea, Andropogon gayanus, Loudetia togoensis, Eragrostis cilianensis, E. tremula and Schoenefeldia gracilis. The most representative families of our study area were Poaceae, Fabaceae and Asteraceae. The Shannon diversity index varied from 4.2 to 5.78 bits, and the Pielou evenness index from 0.77 to 0.85 . The study revealed a progressive evolution of the herbaceous vegetation with a very high proportion of species on the average. Within the framework of a sustainable management of natural resources, our results provide additional information on the floristic composition of the herbaceous vegetation in the sudano-sahelian zone of Cameroon.
\end{abstract}

Keywords: Characterization, herbaceous vegetation, savannah ecosystems, Mayo-Danay Division, Cameroon 